\title{
11 Schoenberg, satire, and the Zeitoper
}

\author{
PETER TREGEAR
}

The end of World War I was an especially difficult time for Schoenberg, as indeed it was for most of his compatriots. It was not only the scarcity of basic necessities such as food and coal that made for uncomfortable living. The total defeat of Austria-Hungary, the collapse of the Habsburg monarchy, the rise of new political movements inspired by the Russian Revolution in November 1917, and the creation of an Austrian Republic in November 1918 were described by the composer as "the overturning of everything one had believed in" " and the beginning of a "war against all that is low and beastly." While his introduction of radical atonality was itself commonly thought to be a violent break with tradition, Schoenberg nevertheless maintained that it was precisely a respect for tradition that ultimately justified his compositional advances. ${ }^{3}$ Now, however, the very idea of deferring to the past seemed in question. The third edition of his Theory of Harmony (1921) warns the reader of the dangers of using the spirit of the postwar age as an excuse for an equally iconoclastic approach to composition. "The sad part," he wrote "is just that the idea, "one may write anything today,' keeps so many young people from first learning something accepted and respectable, from first understanding the classics, from first acquiring Kultur." It was now necessary, he believed, to distinguish between a composer (such as himself) who was a "prophet of the future," preserving and extending an intrinsically valuable musical tradition, and the "modern" composer, who was merely concerned with being "up-to-date." "Masters," he continued, "are the only ones who may never write just anything, but must rather do what is necessary: fulfil their mission."4

It is not surprising then, that both Schoenberg and many of his subsequent defenders preferred to project an image of the composer that was aloof from the messy, contingent world that now surrounded him. ${ }^{5}$ It fitted best with his l'art pour l'art philosophy, and has helped preserve a popular view of the composer as a misanthropic and misunderstood genius. However, Schoenberg was far more directly engaged with postwar cultural and political developments than we have come to recognize, and - ample evidence is to be found not just in his polemical writings, radio 
broadcasts, and teaching, but also in his compositions. Indeed, Schoenberg was particularly conscious at this time of his growing status and fame as a composer, achieved principally through international performances of works such as the Gurrelieder and Pierrot lunaire.

Signs of his growing engagement with postwar culture are already evident in the series of works Schoenberg composed between 1920 and 1923, whose significance today is largely based on the fact that they chart the emergence of the twelve-tone technique. The fifth movement of the otherwise functionally entitled Klavierstücke (Pieces for Piano), Op. 23, is, for instance, a sardonic waltz reminiscent of the many piano dances by Wilhelm Grosz, Ernst Krenek, Karol Rathaus, Egon Wellesz, and others popular at that time. ${ }^{6}$ The eclectic form and unusual scoring of the Serenade, Op. 24 (clarinet, bass clarinet, mandolin, guitar, violin, viola, cello, and baritone) evokes the sound world of contemporary salon orchestras, and the Suite for Piano, Op. 25 is a playful rendering of a baroque keyboard suite, a choice of genre which gives nod to contemporary aesthetic currents associated with the slogans Neoclassicism and Neue Sachlicheit (New Objectivity).

In addition, Schoenberg's marriage in 1924 to Gertrud Kolisch, a woman some 26 years his junior, provided him with a worldly-wise, intelligent, and energetic creative partner. In other ways he was also becoming aware that he was being eclipsed by this "up-to-date" younger generation, some of whom, like Krenek with his Zeitoper (opera of the times) and Jonny spielt auf (Jonny Strikes Up), were to achieve extraordinary popular success in the later half of the 1920s. The fact that a genre like Zeitoper which, as the name suggests, deliberately set out to reflect the aesthetic conditions of contemporary life, had proved so successful irritated and troubled Schoenberg in equal measure. One observable result was that he composed works explicitly satirizing these contemporary composers and the contemporary milieu despite the fact that the equally inescapable worldliness of satire was ultimately in conflict with his emerging self-perception as a "lonely" defender of tradition after the war. ${ }^{7}$ Nevertheless, this conflict of aims and means was nothing if not a creative one, eventually inspiring a curious commentary on the Zeitoper genre, the one-act opera Von heute auf morgen (From Today to Tomorrow), and thereafter helping to shape the dramatic and musical core of Moses und Aron.

\section{Three Satires (Drei Satieren), Op. 28}

The explicit motivation for Schoenberg's first expressly satirical work of the 1920s seems to have been twofold: his negative experiences at the 
Festival of the International Society for New Music in Venice in September 1925 (in particular the success of Stravinsky's Sonata for Piano [1924]), together with the difficulties he experienced rehearsing the Serenade, Op. 24; and reports of a speech critical of Schoenberg given by Krenek at the Congress of Music Aesthetics in Karlsruhe in the following month. ${ }^{8}$ As he later recalled: "I wrote [the Satires] when I was very much angered by attacks of some of my younger contemporaries at this time and I wanted to give them a little warning that it is not good to attack me." The text is far from subtle; the foreword to the three choruses, for instance, refers to "wie der Mediokre neckisch bemerkt" (as the mediocre person cheekily remarks - the pun being in the sound "kre-neck" lying between "Mediokre" and "neckisch." 10 The second movement refers to Stravinsky as "der kleine Modernsky," and the third mocks Hugo Riemann, whose 1916 edition of the Dictionary of Music had been critical of Schoenberg's Theory of Harmony.

Effective satire depends upon an audience's ability to engage closely with the styles and idioms under critique. Here, however, Schoenberg conspicuously avoided extending his satirical impulse to the score. The music is instead composed rigorously in the twelve-tone technique, an analysis of which reveals complex contrapuntal musical patterns. Indeed much later Stravinsky said that while he was upset at Schoenberg's rudeness, he was nevertheless flattered that he would express it using a canon of such ingenuity. ${ }^{11}$ While he would have easily been able to parody and pastiche particular composers' styles, Schoenberg found himself in an aesthetic bind. Composing this kind of novelty could only result in a score characterized by "mannerism, not originality" and as such would be constitutionally obsolete, not new, music, which was a principal criticism he had of the music of Stravinsky. ${ }^{12}$ Indeed, Schoenberg had been particularly annoyed to read a report of a comment that Stravinsky had made in New York early in 1925 that he was quite happy not composing "music of the future," rather he would write "for today."13 Stravinsky's attitude was reflected more widely in the appearance of so-called Gebrauchsmusik (music for use), and music inspired by jazz or film music, or music which tried to reflect in its internal workings the stylistic heterogeneousness of contemporary urban life. Schoenberg's ideal of the authentic musical utterance was, however, constitutionally opposed to such aesthetic pragmatism or concession to popular taste. Music could never be a mere object for enjoyment or a means to some extrinsic end; rather it was a mode of cognition, which required submission to its own internal logic. Any composition which debased this logic in favor of easy gratification was, he thought, functionally obsolete as soon as it was composed, because it was not, in this sense, "new."14 
Schoenberg's attitude owed much to the example of Karl Kraus, who similarly believed that the artist's duty was to maintain a steadfast loyalty to values immanent to the creative medium. ${ }^{15}$ And like Kraus, Schoenberg's insistence upon it took on not only ethical, but also religious - and specifically Jewish-theological - resonances. The first two of the Four Pieces for Mixed Chorus, Op. 27, which were composed around the same time as the Satires, set texts which made the connection quite explicit: "Unentrinnbar," for instance, praises those who have "the strength to conceive of their mission, and the character that will not let them refuse it." The evocation of Jewish theology, and by implication, his Jewish heritage, was in part a response to increasing anti-Semitic attacks. As he wrote to Kandinsky on April 19, 1923, "I have at last learnt the lesson that has been forced upon me during this year, and I shall never forget it. It is that I am not a German, not a European, indeed perhaps scarcely even a human being (at least, the Europeans prefer the worst of their race to me), but I am a Jew." ${ }^{16}$ In a letter to Berg in 1933, Schoenberg reflected upon his then recent reconversion to Judaism by noting that the text of the second movement of Op. 27, "Du sollst nicht, du mußt," was evidence that his return to the Jewish faith had in fact taken place "long ago."17

\section{Schoenberg in Berlin}

This increasing feeling of alienation helped to confirm Schoenberg's sense of himself as one who was destined "to become lonely," that he had the melancholy duty "of developing my ideas for the sake of progress in music, whether I liked it or not; but I also had to realize that the great majority of the public did not like it." ${ }^{\text {18 }}$ Nevertheless, his growing success as a composer also brought with it greater material independence which allowed him to cultivate a more open and comfortable lifestyle. Following the death of Ferruccio Busoni in 1924, Schoenberg, newly married, was wooed to Berlin to teach composition at the Prussian Academy of the Arts (Akademie der Künste) which enabled him to leave, as Stuckenschmidt observed, "many things behind in Vienna which had hitherto inhibited his character." ${ }^{\prime 9}$ In contrast to the Austrian capital, Berlin had recovered from the shock of revolution and the subsequent ravages of hyperinflation with astonishing speed, and had by the middle of the 1920s, as Carl Zuckmayer put it, "a taste of the future about it." ${ }^{\text {20 }}$ It quickly became a center for artists, journalists, painters, and musicians from around the world, keen to discuss the nature of that future and how their art might respond. Their creations in turn filled the galleries, theaters, cinemas, nightclubs, and concert halls helping to create an atmosphere of now-legendary permissiveness and excitement. 
The new, heterogeneous, dramatic forms being presented on the Berlin stage by figures such as Erwin Piscator and, later, Bertolt Brecht must, however, have appeared especially antithetical to Schoenberg. Berlin might well have become the center of gravity of German music, but for Schoenberg, what was lacking was precisely a "center of gravity," that is a collective will to take seriously the kind of technical and ethical concerns that now drove his own compositional style. ${ }^{21}$ His commitment to the twelve-tone technique thus took on implicit political implications, not least in its superficial similarities to calls on the far right of politics for a renewal of German cultural and civil life, and in the context of his reputed comment five years earlier that in twelve-tone music he had "made a discovery which will ensure the supremacy of German music for the next hundred years." Indeed for Schoenberg, the proper register for German music was an art form which would steadfastly maintain the highest ambition, which would "always reach for the heavens." The rest, he declares, "only boasts with artifice." 22 The Suite, Op. 29, for piano, E flat clarinet, clarinet, bass clarinet, violin, viola and cello, and the Third String Quartet, Op. 30, both completed in 1926, not only served as demonstrations of the ability of his new compositional technique to support largescale musical statements through atonal similes to sonata form or to replicate complex contrapuntal structures, but also showed his continuing commitment to the traditional forms of chamber music, and by extension, to the German ideal of absolute music. These compositional explorations culminated in the two Pieces for Piano, Op. 33a (1929) and 33b (1931) and his first composition for large orchestra since the Orchestral Songs, Op. 22 (1914-16), the Variations for Orchestra, Op. 31, which, in its incorporation of the B-A-C-H motive, registers its affiliation to the heart of the German musical pantheon.

\section{Von heute auf morgen}

And yet, soon after his arrival in Berlin, Schoenberg also made a decisive return to explicitly dramatic forms of music, something that he had avoided since the abandonment of the composition of Die Jakobsleiter (Jacob's Ladder) in 1922. In June 1926 he began work on his play Der biblische Weg (The Biblical Way) and by October 1928 he had drafted the first version of the text of Moses und Aron, then in the form of an oratorio. The composition of the music of Moses und Aron, however, was not to commence for some years. Instead, in October 1928 Schoenberg began work on Von heute auf morgen. The libretto, penned by Gertrud Schoenberg, writing under the pseudonym of Max Blonda, was apparently inspired in part by the manner of some of Schoenberg's circle of friends. ${ }^{23}$ Gertrud had at this time also been working closely with her husband on 
several other libretti on contemporary subjects, including, it seems, one set in Monte Carlo, and another, with echoes of Debussy's Jeux, revolving around an international tennis competition. ${ }^{24}$

Von heute auf morgen became Schoenberg's most overt confrontation with the culture of the Weimar Republic. Like the Three Satires it was prompted in part by his annoyance at the extraordinary successes of a younger generation of composers, which at the time of its composition included not just Krenek's Jonny spielt auf, but also Kurt Weill's Der Zar läßt sich photographieren (The Tsar Has His Photograph Taken) and Hindemith's Hin und zurück (There and Back). These archetypal Zeitopern were for Schoenberg, as they have often been for many a critic since, representative of a shamelessly ephemeral genre, and thus constitutionally antithetical, it seemed, to the idea of authentic art. Von heute auf morgen thus satirizes both modern life and modern art. As he noted in his own introduction to a radio broadcast of the work that he conducted in Berlin on February 27, 1930, "the matter becomes serious when fashionable slogans shake the foundations of private life, the relationship between the sexes and the institution of marriage.... [W] hen the foundations are destroyed, rebuilding can only be superficial." ${ }^{25}$ The consumer of the Zeitoper is by implication like the husband in the opera with the wandering eye, who is told by his wife that "behind the glittering mask you imagine a marvellous creation. You are dazzled by every new apparition that is fashionably dressed. But once the charm of novelty has worn off, you gaze disappointed into nothing." 26

Once again, however, Schoenberg was also confronted with the problem of satire itself, which, given the inherently worldly, satirical, nature of the Zeitoper genre, was here especially acute. In both, an ideal norm of form or content is often conspicuous by its absence; rather the composer of a Zeitoper seems to share with the satirist a hope that an intended audience "will go through the strengthening exercise of finding it themselves." 27 Thus, a Zeitoper will make a virtue of the absence of an apparently consistent compositional voice, instead foregrounding devices such as parody, pastiche, and displays of the grotesque, forcing us to reflect on what might constitute an authentic aesthetic utterance in the modern world. ${ }^{28}$ Schoenberg's opera, however, conspicuously avoids such a strategy. While there are signs of an attempt at musical satire through the use of instruments associated with the cabaret and nightclub (such as the soprano and alto saxophone, flexatone, piano, mandolin, and guitar), fleeting references to a tango, and even a brief quotation from Act I of Wagner's Die Walküre, typically such references are fully integrated into the overall timbre and dodecaphonic structure of the work, and thus softened in effect if not placed beyond our immediate grasp. "Better 
colourless than crude - better no humour than this disgusting slapstick which is rampant in Berlin," he wrote. ${ }^{29}$ Even an easy opportunity to mimic Zeitoper stage effects, such as the "entrance" of one character by means of the telephone, is consciously avoided. Schoenberg notes in the score that the effect of a telephone call is to be achieved naturally, and "under no account via loudspeakers or megaphones," as if he wanted consciously to negate the craving for novelty that had followed in the wake of the appearance of such technology in Jonny spielt auf..$^{30}$

The music is instead concerned principally with internal consistency, though we might note that the treatment of the twelve-tone row is here more supple than hitherto apparent in Schoenberg's dodecaphonic music, moving from a strict ordering of notes within a row toward free permutations of notes within hexachords. Nevertheless, both Rognoni and Rufer, apparently taking a lead from Schoenberg himself, saw this as a development once again supported by tradition, as it could be thought of as being analogous to Rameau's principle that the harmonic identity of a triad remained essentially the same, whatever the inversion in which it was found. It was justified ultimately by the "unity of the soundspace, where horizontal and vertical elements are considered as aspects substantially identical." ${ }^{\text {31 }}$ The force of musical tradition seems also to have influenced the overall form of the work, which can be considered as a kind of secret numbers opera within which passages of recitative are punctuated by short sections of arioso, arias, and ensembles. It is even possible to detect the outline of a classical four-movement symphony form; ${ }^{32}$ though in so doing we would do well to remember Derrick Puffett's observation that these are usually not so much objective truth claims as "a representation of a certain way of seeing things, a way which we know from all kinds of evidence to have been characteristic of Schoenberg and his circle." ${ }^{33}$

Schoenberg suggested elsewhere that it was the libretto which held the key to the work's overall character, that "behind the straightforward plot something else is hidden: [namely] that everyday figures and events are being used to show how above and beyond the simple marital story the socalled modern, the fashionable exist only 'from one day to the next' (Von heute auf morgen), from an unsteady hand to a greedy mouth, in marriage no less than in art, in politics and in life philosophies." ${ }^{34}$ The form and dramatic function of the music of Von heute auf morgen is then perhaps most concisely expressed by Adorno, who in his review of the work in 1930 wrote that "the music consumed the libretto." ${ }^{35}$ Or, as Rognoni more expansively put it, "alienation does not invest in the artist's language, but is simply 'described' as an external fact which may be objectively dismantled and reconstructed by the composer like a sort of shifting collage." We observe the story unfold, all the while the music stares us 
down, like one of Schoenberg's famous self-portraits, demanding us to maintain an unwaveringly distant and critical standpoint towards it.

All the same, it could be argued that the stylistic montage evident in contemporary Zeitoper is ultimately a more effective artistic gesture for transporting a social context into a critical aesthetic sanctuary. At the very least, it makes for more effective, but also more approachable, satire. It is therefore hard to believe that at the same time, Schoenberg thought that this work would have the same kind of commercial success as was greeting other new works in the 1929-30 season, such as Max Brand's Maschinist Hopkins, Brecht and Weill's Aufstieg und Fall der Stadt Mahagonny (Rise and Fall of the City of Mahagonny), or Hindemith's Neues von Tage (News of the Day), the last of which superficially deals with some of the same subject matter. And yet so confident was he of its success that he rejected an offer of 30,000 marks from Bote und Bock for the publication rights, a decision that later proved financially disastrous. ${ }^{37}$ Perhaps, as Adorno notes, "[e]ven if Schoenberg with his comedy Von heute auf morgen, was searching for success, it was - to his honour - refused him, by the complexity and the dark ferocity of its music ... The antinomy of opera and public came out to be a victory for the composition upon the opera." ${ }^{\text {38 }}$ Certainly compared to Schoenberg's other major works, Von heute auf morgen has had few performances - though it is a fate that it, of course, now shares with the vast majority of the Zeitoper genre.

\section{Accompaniment to a film-scene (Begleitungsmusik zu einer Lichtspielszene)}

Schoenberg's preoccupation with contemporary culture at this time is also reflected in his interest in cinema. He considered introducing a film sequence into Moses und Aron for the "Dance Around the Golden Calf," and had also discussed the use of film with Alban Berg who was later to recommend its use in the staging of his opera Lulu. The Begleitungsmusik $z u$ einer Lichtspielszene, Op. 34 (1930) was composed in response to a commission by the publisher Heinrichshofen, and stands as Schoenberg's most overt artistic response to the burgeoning genre of film music, one then on the cusp of moving decisively from the live theater pit to the sound track. While not conceived with an actual visual narrative in mind, Schoenberg did offer the following synopsis for the work: Fear Threatening Danger - Catastrophe. In so doing he may have been alluding to the books of themed musical excerpts that were the stock-in-trade of the silent movie accompanist. Both the quasi-expressionist synopsis and the fact that the music proved a success with contemporary audiences, 
though, also bring to mind the popular complaint made of later twelvetone music that it rather lends itself to being used as the accompaniment to horror films. Certainly, as Dahlhaus wrote, in articulating the implied expressive content, the programmatic titles "transform [the work] into an illustrative one $\therefore$ The listener feels he has been placed in the role of a spectator instead of being himself directly affected; and since it is film music (albeit only fictitious) he accepts the dissonances he would otherwise not tolerate." ${ }^{39}$ Perhaps Schoenberg sensed this potential corruption of the relationship between the listener and the score when he tellingly remarked, "[The public] seem to like the piece - should I draw conclusions as to its quality?"40 Later, in America, Schoenberg dabbled with the possibilities of film music once again, this time to accompany MetroGoldwyn-Mayer's The Good Earth, but he could not accept the necessary level of compromise and subordination to the needs of the studio that the task would have required.

Another work from this time, the Six Pieces for Male Chorus, Op. 35 (1930) is also concerned with the relationship between an artist and society, not least because it was written for, and performed by, workers' choruses, but the work also demonstrates an attempt by the composer to mediate between tonal and twelve-tone systems. The texts set are again by Schoenberg, yet this time his concerns are not satirical but rather deliberately serious. In this respect they seem an apt precursor to Moses und Aron, the work to which Schoenberg was now returning with renewed vigor. And yet, that work too should be seen as but another elaboration, albeit now on an abstracted and monumental scale, of his struggle to articulate a musical response to the art and politics of the Weimar Republic without thereby becoming tainted by it. As Joseph Auner suggests, the metaphor of Moses and Aaron was only meaningful to him precisely because of the "tension and ambivalence" that had come to characterize his relationship to his public during the Weimar years. ${ }^{41}$

\section{Conclusion}

Given how decisively Moses und Aron seems to conceal the satiric impulse that is apparent in many of the works that it precedes, it has been easy to downplay or forget this broader historical context. Arguably, Schoenberg's reputation has suffered for it. Certainly in the hands of his critics both then and subsequently, his professed belief in l'art pour l'art became a statement that suggested both an unpleasant arrogance and an apparent lack of concern for social engagement through art. ${ }^{42}$ Today the notion that a direct engagement with popular culture must always be destructive of the 
idea of authentic art arouses at the very least our suspicion, at worst, our derision. For all this, however, Schoenberg deserves not so much to be blamed as understood. Recognizing that he, like a character in Der biblische Weg, was "cursed by wishing to be Moses and Aaron wrapped up in one," allows us to resolve the apparent contradiction in his music of the 1920 s between a profound commitment to the twelve-tone technique, and a genuine desire to engage with forms of popular culture. Although, in the end, Schoenberg did feel compelled towards a definitively antagonistic position towards mainstream culture, it is also worth remembering that he was far from alone in choosing such a path. It is more than merely ironic that both Krenek and, eventually, Stravinsky were themselves to adopt the twelve-tone technique in terms not altogether removed from those Schoenberg had come to represent in dramatic form at this time. While today we can take a considerably more nuanced view of the oppositions between high and low culture that buttressed much of his creative selfimage, for many who followed more immediately in his footsteps, the effects of the stock market crash in America in October 1929 and the subsequent rise to power of the National Socialists in Germany seemed only to confirm the righteousness of the ethical stance that his music had come to represent. Such is the weight of history that has come to haunt our reception of Schoenberg, man and musician, from the Weimar era. 
40. Letter from Schoenberg to Anny Winslow dated May 23, 1923. Dümling, "Schönberg und sein Schüler Hanns Eisler,” 256.

41. Brecht journal entry dated April 27, 1942. Journals 1934-1955, eds. J. Willett and

R. Manheim, (London: Routledge, 1993), 224.

42. Brecht journal entry dated July 29, 1942. Journals, 251.

43. Eisler, "Notes to Dr. Faustus," trans.

K. von Abrams in D. Blake (ed.) Eisler: $A$

Miscellany, 252-6.

Chapter 11 Schoenberg, satire, and the Zeitoper 1. Schoenberg to Kandinsky, July 20, 1922, Arnold Schoenberg/WassilyKandinsky: Letters, Pictures and Documents: ed. J. Hahl-Koch, trans. J. C. Crawford (London: Faber, 1984), 74.

2. Schoenberg to Fromaigeat, July 22, 1919, Arnold Schoenberg Letters, ed. E. Stein, trans. E. Wilkins and E. Kaiser (London: Faber, 1964), 67.

3. Adorno later wrote that in Habsburg Vienna the "constituent traditionalism protested ... against the tradition itself and revolutionized it with the demand that it take itself seriously," in T. W. Adorno, Quasi una Fantasia: Essays on Modern Music, trans. R. Livingstone (London, Verso, 1992), 204. Similarly, René Leibowitz argues, "there is not a break, but a continuity between [the works composed in the new system and the works which led to the discovery of this system]," in Schoenberg and His School: The Contemporary Stage of the Language of Music, trans.

D. Newlin (New York: Philosophical Library, 1949), 104.

4. A. Schoenberg, Theory of Harmony, trans.

R. E. Carter (London: Faber, 1978), 433.

5. The "conservative revolutionary," as

Malcolm MacDonald suggests, had become a "revolutionary conservative." M. MacDonald, Schoenberg (London: J. M. Dent, 1976), 52. See also J. Auner, "Proclaiming a Mainstream" in The Cambridge History of Twentieth-Century Music, N. Cook and A. Pople (eds.), (Cambridge University Press, 2004), 228-59.

Carl Dahlhaus writes that it was characteristic of Schoenberg for "musically revolutionary and conservative traits" to cancel each other out. See C. Dahlhaus, Schoenberg and the New Music, trans. D. Puffett and

A. Clayton (Cambridge University Press, 1987), 102.

6. See, for instance, the Grotesken-Album published by Universal Edition, Vienna, in 1920. 7. See Schoenberg, "How One Becomes Lonely" (1937), in Style and Idea: Selected
Writings of Arnold Schoenberg, ed. L. Stein, trans. L. Black (London: Faber, 1975), 30-53. 8. See H. H. Stuckenschmidt, Schoenberg: His Life, World, and Work (New York: Schirmer, 1978), 308-9; Krenek, "Music of Today," Address to the Congress of Music Aesthetics in Karlsruhe, October 19, 1925; trans. S. C. Cook, Opera for a New Republic: The Zeitopern of Krenek, Weill, and Hindemith (Ann Arbor: UMI Research Press, 1988), 193-203.

9. Schoenberg to Amadeo de Filippi, May 13, 1949, Arnold Schoenberg Letters, 271-2.

10. Krenek may possibly have had his revenge in the opening lines of Jonny spielt auf, in which the gloomy composer Max sings of his "Lovely Mountain ["schöner Berg"], who attracts me, who compels me to abandon my home, my work."

11. G. Watkins, "The Canon and Stravinsky's Late Style," Confronting Stravinsky: Man, Musician, and Modernist, ed. J. Pasler (Berkeley: University of California Press, 1986), 239.

12. Schoenberg, "Criteria for the Evaluation of Music," draft lecture from 1927, revised 1946, republished in Style and Idea, 134.

13. Quoted in S. Walsh, Stravinsky: A Creative Spring (New York: Alfred A. Knopf, 1999), 421. See also L. Stein, "Schoenberg and 'Kleine Modernsky," Confronting Stravinsky, 310-11. 14. Schoenberg, "New Music, Outmoded, Music, Style and Idea," lecture, March 22, 1931, revised February 10, 1933, reproduced in Style and Idea, 113-23.

15. See A. Goehr, "Schoenbergand Karl Kraus: The Idea behind the Music," Music Analysis, 4/1 (1985), 59-71.

16. Schoenberg to Kandinsky, April 19, 1923, Auner, A Schoenberg Reader, 168.

17. Schoenberg to Berg, October 1, 1933, J. Brand, C. Hailey, and D. Harris (eds), The Berg-Schoenberg Correspondence: Selected Letters (New York: W. W. Norton, 1987), 446; quoted in Auner, A Schoenberg Reader, 185. 18. Schoenberg, "How One Becomes Lonely" (1937), Style and Idea. 53.

19. H. H. Stuckenschmidt, Arnold Schoenberg (New York, Grove Press, 1960), 94.

20. C. Zuckmayer, Als wär's ein Stück von mir. Horen der Freundschaft (Frankfurt: S. Fischer Verlag, 1966), 314.

21. Schoenberg to Deutsche Allgemeine Zeitung (Berlin), June 18, 1930, in response to a question circulated to prominent national musicians about "musical life and a shift of the centre of gravity from Vienna to Berlin." See Arnold Schoenberg Letters, 142. 
22. Schoenberg, aphorism published in Der getreue Eckhart 2/11 (1921), 512-13. This statement, which appeared in an issue entitled "The meaning of music for German culture," was prefaced by an editorial note that reminded the reader that Schoenberg was an artist who belonged to "the extreme left," who "on the basis of his latest works can be regarded as an outspoken advocate of atonalism and anarchy in music." Even he, it was noted, nevertheless concedes the uniquely valuable aspects of German culture. Trans. adapted from Maja Reid, reproduced in Auner, A Schoenberg Reader, 160. In his "National Music (2)" (1931), Style and Idea, 172-4, Schoenberg draws attention to the close links he saw between his music and the canonic German composers such as Bach, Mozart, Beethoven, and Wagner.

23. According to documents among the papers of Schoenberg's son-in-law Felix Greissle, it may have been based in part upon the domestic life of the Greissles, although the librettist told Leopoldina Gerhard that noted opera composer (and Schoenberg's close friend) Franz Schreker and his wife were the models. See J. Brand, "Of Authorship and Partnership: The Libretto of Von heute auf morgen,"Journal of the Arnold Schoenberg Institute 14 (1991), 158.

24. See J. Shaw, "The Republic of the Mind," Music, Theatre, and Politics in Germany: 1848 to the Third Reich, ed. N. Bacht (Aldershot: Ashgate, 2006), 202-3.

25. Schoenberg, "An Introduction to a Broadcast of Von heute auf morgen," in Auner, A Schoenberg Reader, 220.

26. Frau: "Ich weiss ja, dass dich zu diesen Frauen nur die Neugier zieht; dass du dir hinter der glänzenden Maske ein phantastisches Wunder erhoffst. Von jeder neuen Erscheinung, die sich modisch gibt, bist du geblendet. Doch ist der Reiz der Neuheit vorbei, blickst du enttäuscht ins Nichts." Von heute auf morgen, mm. 224-38.

27. C. Witke, Latin Satire: The Structure of Persuasion (Leiden: Brill, 1970), 13.

28. See P. Tregear, "Stadtluft macht frei': Urban Consciousness in Weimar Opera," Music, Theatre, and Politics in Germany: 1848 to the Third Reich, ed. N. Bacht, 237-54.

29. Schoenberg to Steinberg, October 4, 1929, (Rufer/Newlin, 56).

30. L. Rognoni, Second Vienna School, trans. R. W. Mann (London: John Calder, 1977), 264.

31. Ibid., 197. J. Rufer, Composition with Twelve Tones, trans. H. Searle (London: Rockliff, 1954),
184. R. Gerhard, "Tonality in Twelve-Tone Music," The Score, 6 (1952), 23-35.

32. See K. Kalchschmid, "Zwölf Töne gegen die Mode: Zur Music-Dramaturgie in Schönbergs erster Zwölfton-Oper," Von heute auf morgen: Oper - Musik - Film; Drehbuch und Materialien zum Film von Danièle Huillet \& Jean-Marie Straub und zur Oper von Arnold \& Gertrud Schönberg, ed. K. Volkmer, K. Kalchschmid, P. Primavesi (Berlin: Vorwerk-8, 1997), 73-85.

33. D. Puffett, "'Music that Echoes Within One' for a Lifetime: Berg's Reception of Schoenberg's Pelleas und Melisande," Music and Letters 76 (1995), 209-64. 34. Schoenberg to Wilhelm Steinberg, October 4, 1929, quoted in J. Brand, "A Short History of Von heute auf morgen with Letters and Documents," Journal of the Arnold Schoenberg Institute 14 (1991), 248-9. 35. T. Adorno, "Arnold Schönberg: Von heute auf morgen," Die Musik 22 (1930), 446.

36. Rognoni, Second Vienna School, 195.

37. See Brand, "A Short History of Von heute auf morgen," 252.

38. T. Adorno, Introduction to the Sociolog of Music, trans. E. B. Ashton (New York: The Seabury Press, 1976), xxx.

39. C. Dahlhaus, Schoenberg and the New Music, trans. D. Puffett and A. Clayton

(Cambridge University Press, 1987), 102.

40. Schoenberg to Heinrich Jalowetz, in E. Stein (ed.), Arnold Schoenberg Letters, trans. E. Wilkins and E. Kaiser (London: Faber, 1964), 148. In 1973 the French film director Jean-Marie Straub produced a film to accompany the music.

41. J. Auner, "Schoenberg and His Public in 1930: The Six Pieces for Male Chorus, Op. 35," Schoenberg and His World, ed. W. Frisch (Princeton University Press, 1999), 116. 42. See, for instance, W. J., "Arnold Schoenberg's Idea," Kölnische Zeitung, February 11, 1933; quoted in J. Auner, "Arnold Schoenberg Speaks: Newspaper Accounts of His Lectures and Interviews, 1927-1933," in W. Frisch (ed.), Schoenberg and His World, 279.

Chapter 12 Schoenberg's row tables 1. See J. Auner, "In Schoenberg's Workshop: Aggregates and Referential Collections in the Composition of Die glückliche Hand," Music Theory Spectrum 18/1 (1996), 77-105; E. Haimo, Schoenberg's Serial Odyssey: The Evolution of his Twelve-Tone Method, 1914-1928 (London and New York: Oxford University Press, 1990); B. Simms, The Atonal 


\section{University Library}

\section{- M M I N E R VA A gateway to Melbourne's research publications}

Minerva Access is the Institutional Repository of The University of Melbourne

Author/s:

Tregear, PJT

Title:

Schoenberg, satire, and the Zeitoper.

Date:

2010

Citation:

Tregear, P. J. T. (2010). Schoenberg, satire, and the Zeitoper.. The Cambridge Companion to Schoenberg, (1), pp.147-156. Cambridge University Press.

Persistent Link:

http://hdl.handle.net/11343/29797 